Brazilian Journal of Microbiology (2009) 40: 612-622

ISSN 1517-8382

\title{
PRODUCTION OF THERMOSTABLE INVERTASES BY ASPERGILLUS CAESPITOSUS UNDER SUBMERGED OR SOLID STATE FERMENTATION USING AGROINDUSTRIAL RESIDUES AS CARBON SOURCE
}

\author{
Ana Cláudia Paiva Alegre, Maria de Lourdes Teixeira de Moraes Polizeli, \\ Héctor Francisco Terenzi, João Atílio Jorge, Luis Henrique Souza Guimarães*
}

Departamento de Biologia, Faculdade de Filosofia, Ciências e Letras de Ribeirão Preto, Universidade de São Paulo, Ribeirão Preto, SP, Brasil

Submitted: September 29, 2008; Returned to authors for corrections: November 12, 2008; Approved: May $04,2009$.

\begin{abstract}
The filamentous fungus Aspergillus caespitosus was a good producer of intracellular and extracellular invertases under submerged (SbmF) or solid-state fermentation (SSF), using agroindustrial residues, such as wheat bran, as carbon source. The production of extracellular enzyme under SSF at $30^{\circ} \mathrm{C}$, for $72 \mathrm{~h}$, was enhanced using SR salt solution (1:1, w/v) to humidify the substrate. The extracellular activity under SSF using wheat bran was around 5.5-fold higher than that obtained in SbmF (Khanna medium) with the same carbon source. However, the production of enzyme with wheat bran plus oat meal was 2.2-fold higher than wheat bran isolated. The enzymatic production was affected by supplementation with nitrogen and phosphate sources. The addition of glucose in SbmF and SSF promoted the decreasing of extracellular activity, but the intracellular form obtained in SbmF was enhanced 3-5-fold. The invertase produced in $\mathrm{SSF}$ exhibited optimum temperature at $50^{\circ} \mathrm{C}$ while the extra- and intracellular enzymes produced in $\mathrm{SbmF}$ exhibited maximal activities at $60^{\circ} \mathrm{C}$. All enzymatic forms exhibited maximal activities at $\mathrm{pH} 4.0-6.0$ and were stable up to 1 hour at $50^{\circ} \mathrm{C}$.
\end{abstract}

Key words: Aspergillus caespitosus, $\beta$-D-fructofuranosidase, invertase, solid-state fermentation, submerged fermentation

\section{INTRODUCTION}

The inverted sugar, a 1:1 mixture of dextrorotatory Dglucose and levorotatory D-fructose, is obtained by hydrolysis of sucrose by invertase, also named $\beta$-Dfructofuranosidase (EC 3.2.1.26). Invertase is one of the most widely used industrial enzymes that is also able to catalyze the hydrolysis of raffinose and stachyose $(4,5)$. In addition,

*Corresponding Author. Mailing address: Departamento de Biologia - Faculdade de Filosofia, Ciências e Letras de Ribeirão Preto - USP, Avenida Bandeirantes 3900, 14040-901 Ribeirão Preto-SP, Brasil.; phone: + 55 (16) 3602-4682 fax: +55 (16) 3602-4886.; Email: 1hguimaraes@ffclrp.usp.br 
it may be used to obtain fructooligosaccharides (FOS), used as prebiotic substance (35). Invertase is classified in the GH32 family of glycoside hydrolases, that includes over 370 members (2) and has been reported in plant (28), bacteria (34), yeast $(4,12)$ and filamentous fungi, as Aspergillus ochraceus (11), Aspergillus niger (24), Aspergillus japonicus (7) and Thermomyces lanuginosus (6).

Invertases may be found in different isoforms according to their $\mathrm{pH}$ optimum. However, the specific function of these isoforms is not well-known, but they appear to control the entry of sucrose into different utilization pathways (28). The acidic form has cell-wall or vacuolar localization and it is evolutionary related to yeast and bacterial invertases (28), differing of neutral and alkaline isoforms that are found on the cytosol (33). In yeast, the gene Suc 2 encodes two different invertases, a glycosilated form located in periplasmic space and a non-glycosilated form situated in the cytosol (12).

The production of invertase by filamentous fungi under submerged (SbmF) or solid-sate (SSF) fermentation has been reported $(3,23)$. SSF is characterized by development of microorganism in a low aqueous content on a non-soluble material that can act as physical support and in some times also as nutrient sources (31). Generally, the enzymatic production in SSF has advantages over SbmF, as higher productivity fermentation, absence of contaminant organisms, concentrated product formation and use of agroindustrial residues as substrates (26). There are many works that show the fructosidase production in SbmF and SSF (26). The aim of this work was to study the production and expression of acidic thermostable invertases by Aspergillus caespitosus under submerged fermentation or solid-state fermentation.

\section{MATERIAL AND METHODS}

\section{Microorganism and culture conditions}

A. caespitosus (21) was isolated from Brazilian soil (10) and identified by André Tosello Foundation (Campinas, SP, Brazil). The organism was maintained on slants of PDA medium. For SbmF, a conidial suspension of $10^{5}$ spores $/ \mathrm{mL}$ was inoculated in Erlenmeyer flasks containing $25 \mathrm{~mL}$ of different media: Khanna (13), SR (22), M5 (18) and Adams (1), initial $\mathrm{pH}$ equal to 6.0. Saccharides $(2 \% \mathrm{w} / \mathrm{v})$ and agroindustrial residues $(1 \% \mathrm{w} / \mathrm{v})$ were used as carbon source in Khanna medium. Agroindustrial residues were used in crude state, without pretreatment. The cultures were incubated at $40{ }^{\circ} \mathrm{C}$ with agitation $(100 \mathrm{rpm})$, in an orbital shaker, for $72 \mathrm{~h}$. SSF was prepared using different agroindustrial residues as substrate/carbon source in Erlenmeyer flasks with $8 \mathrm{~g}$ of substrate humidified with water or a salt solution, closed with cotton and maintained at $70 \%$ relative humidity controlled by digital thermo-hygrometer. Other conditions of growth were the same as those used for liquid cultures.

\section{Influence of several compounds on the invertases production in SbmF and SSF}

Flasks containing $25 \mathrm{ml}$ of SbmF (Khanna medium) or SSF, both with wheat bran as carbon source, were supplemented with nitrogen $\left(\left(\mathrm{NH}_{4}\right)_{2} \mathrm{SO}_{4}\right.$ and peptone) and phosphate $\left(\mathrm{KH}_{2} \mathrm{PO}_{4}\right.$ and $\left.\mathrm{Na}_{2} \mathrm{PO}_{4}\right)$ sources at $1 \%(\mathrm{w} / \mathrm{v})$ for SbmF and $1 \mathrm{ml}$ of a $1 \%$ solution/g substrate for SSF and incubated for $72 \mathrm{~h}$, at $40^{\circ} \mathrm{C}$. Different concentrations of glucose $(0.1-2.0 \%, \mathrm{w} / \mathrm{v}$ or $1 \mathrm{ml} / \mathrm{g}$ substrate) were also added in the SbmF and SSF media supplemented with wheat bran as mentioned and incubated in the same condition described above.

\section{Influence of wheat bran moistened with different solutions}

In this test, maintaining the proportion $1: 1(\mathrm{w} / \mathrm{v})$ between 
solid material and solution, the wheat bran was used as carbon source and it was moistened with different solutions (distilled water, tap water, Khanna or SR salt solutions) and the inoculation was done as described above. The cultures were incubated on $40^{\circ} \mathrm{C}$ during 72 hours in a stove with relative humidity around $70 \%$. In another test, the wheat bran was mixed in three different proportions $(1: 1,1: 2$ and 1:4 w/v) with SR salt solution and incubated on $30^{\circ} \mathrm{C}$ and $40^{\circ} \mathrm{C}$ with the same humidity condition. The medium humidity was determined as:

\section{(HW-DW) $\times 100$ DW}

HW: Humidity weight after sterilization;

DW: Dried weight.

\section{Extraction of extracellular and intracellular enzymes}

The cultures on SbmF were harvested by vacuum filtration using Watman $n^{\circ} 1$ filter paper and the filtrate (extracellular crude extract) was used for enzymatic activity quantification. The mycelia were disrupted in a porcelain mortar with acid-washed sea sand at $4^{\circ} \mathrm{C}$, extracted in distilled water and centrifuged (23000g) for 10 minutes. The supernatant was called intracellular crude extract and was used to determine intracellular invertase activity. $50 \mathrm{ml}$ of distilled water were added in $8 \mathrm{~g}$ of SSF cultures and submitted agitation by 30 minutes using a magnetic stirrer, at $4^{\circ} \mathrm{C}$. After this time, the suspension was vacuum filtered. The obtained filtrate was centrifuged $(23000 g)$ to remove the residues and the supernatant was used to determine the invertase activity.

\section{Enzymatic assay}

The $\beta$-D-fructofuranosidase activity was determined using $1 \%$ sucrose as substrate in sodium acetate buffer, 100
$\mathrm{mM}, \mathrm{pH}$ 4.5. The reaction mixture was composed by 200 $\mu \mathrm{l}$ of buffer added of substrate and $200 \mu \mathrm{l}$ of enzymatic sample. The reaction was carried out at different times at the desired temperatures. The reactions were stopped by DNS and the reducing sugars were quantified according to Miller (16), at $540 \mathrm{~nm}$. One unit of enzyme activity (U) was defined as amount of enzyme that releases $1 \mu \mathrm{mol}$ of glucose per min under the assay conditions. The values of enzymatic activity were expressed as $\mathrm{U} / \mathrm{ml}$ for $\mathrm{SbmF}$ or $\mathrm{U} / \mathrm{g}$ of substrate for SSF.

\section{Protein quantification}

The protein quantification was made according to Lowry et al. (15) using BSA as standard.

\section{Statistical Analysis}

All results are expressed as the mean of three independent experiments with Standard Deviation ( \pm SD).

\section{RESULTS}

\section{Production of invertases on SbmF and SSF}

The highest levels of extracellular invertase activity in SbmF were obtained when the fungus was cultured in Khanna medium (301 U) and SR medium (197 U) after $72 \mathrm{~h}$ under orbital agitation, with wheat bran as carbon source. The best production for the intracellular form occurred in SR medium (146 U) and M5 medium (127 U) (figure 1). The level of the extracellular form was approximately 2-fold higher than the intracellular form. Other agroindustrial residues used as carbon sources in Khanna medium (table 1) also stimulated the invertase production and secretion, as oat meal $(6.2 \mathrm{U} / \mathrm{ml})$, rice straw $(4.2 \mathrm{U} / \mathrm{ml})$ and sugar cane bagasse $(2.2 \mathrm{U} / \mathrm{ml})$ among others. High levels of intracellular form were obtained with sucrose, glucose and wheat bran as carbon sources added to Khanna medium. 
Table 1. Influence of carbon sources on the production of extracellular and intracellular invertases in submerged fermentation by Aspergillus caespitosus.

\begin{tabular}{lccc}
\hline \multicolumn{1}{c}{ Carbon Source } & \multicolumn{2}{c}{ Invertase Activity (U/ml) } & $\begin{array}{c}\text { Intracellular Protein } \\
(\mathbf{m g} / \mathbf{m l})\end{array}$ \\
\cline { 2 - 3 } & Extracellular & Intracellular & $0.1 \pm 0.08$ \\
Without & $0.7 \pm 0.02$ & $0.1 \pm 0.08$ & $0.3 \pm 0.07$ \\
Sucrose & $0.6 \pm 0.11$ & $15.8 \pm 5.15$ & $0.2 \pm 0.01$ \\
Glucose & $0.2 \pm 0.03$ & $6.9 \pm 0.20$ & $0.1 \pm 0.01$ \\
Maltose & $0.1 \pm 0.01$ & $0.1 \pm 0.02$ & $0.2 \pm 0.02$ \\
Starch & $0.2 \pm 0.01$ & $1.2 \pm 0.13$ & $0.1 \pm 0.02$ \\
Wheat bran & $19.1 \pm 0.19$ & $4.1 \pm 0.01$ & $0.2 \pm 0.01$ \\
Oat meal & $6.2 \pm 0.67$ & $0.7 \pm 0.01$ & $0.6 \pm 0.01$ \\
Lactose & $0.8 \pm 0.07$ & $2.5 \pm 0.15$ & $0.3 \pm 0.07$ \\
Crushed Corn & $3.7 \pm 1.15$ & $1.0 \pm 0.33$ & $1.0 \pm 0.48$ \\
Rice straw & $4.2 \pm 0.17$ & $2.6 \pm 1.75$ & $0.2 \pm 0.03$ \\
Raffinose & $0.4 \pm 0.03$ & $1.7 \pm 0.35$ & $0.3 \pm 0.10$ \\
Crushed Corncob & $1.1 \pm 0.19$ & $0.2 \pm 0.08$ & $0.1 \pm 0.01$ \\
Sugar cane bagasse & $2.2 \pm 0.11$ & $2.9 \pm 0.76$ & $0.1 \pm 0.02$ \\
Cassava flour & $0.2 \pm 0.06$ & $0.3 \pm 0.08$ & $0.1 \pm 0.05$ \\
Avicel & $0.6 \pm 0.16$ & $0.3 \pm 0.01$ & $0.2 \pm 0.10$ \\
Quitin & $0.8 \pm 0.03$ & $0.1 \pm 0.01$ & \\
\hline
\end{tabular}

The fungus was grown in Khanna medium in orbital agitation $(100 \mathrm{rpm})$, for $72 \mathrm{~h}$, at $40^{\circ} \mathrm{C}$.

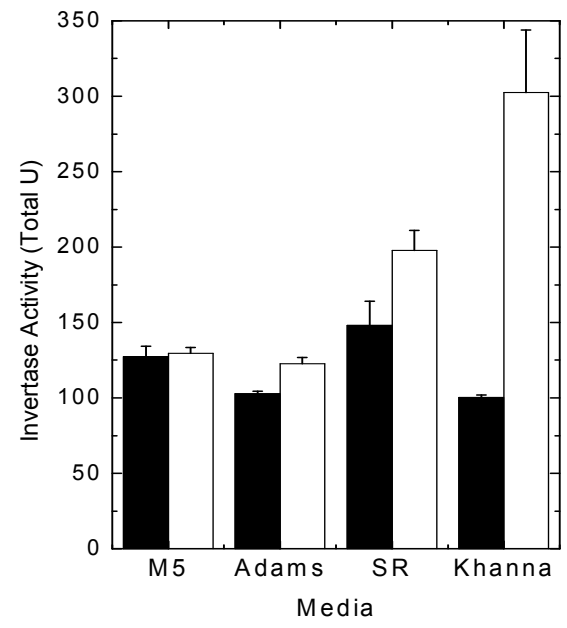

Figure 1. Production of intracellular and extracellular invertases using different culture medium (SbmF) by Aspergillus caespitosus. The culture was maintained in orbital agitation $(100 \mathrm{rpm})$, at $40^{\circ} \mathrm{C}$ by $72 \mathrm{~h}$. Symbols:

intracellular; $(\square)$ extracellular. Total $\mathrm{U}=\mathrm{U} / \mathrm{ml} \mathrm{x}$ volume of crude extract.

Under SSF (table 2), the fungus was grown in wheat bran or soybean bran and produced $117.4 \mathrm{U} / \mathrm{g}$ and $28.3 \mathrm{U} / \mathrm{g}$ of invertase, respectively. Invertase activity was not detected when rice straw, sugar cane bagasse or crushed corncob were used as carbon source, contrasting with the results obtained 
with SbmF. However the enzymatic activity was enhanced when these substrates were combined, and maximal activity was obtained with a mixture of wheat bran and oat meal (181.8 U/g).

Influence of glucose on the invertase production under SbmF and SSF

The production of invertases by $A$. caespitosus under SbmF and SSF in media using wheat bran was affected by the addition of glucose (figure 2A). The extracellular activity produced under SbmF decreased with increasing glucose concentration, arriving at $7 \%$ of initial activity at $2.0 \%$ glucose. In the presence of $1 \%$ glucose the level of intracellular invertase was around 5-fold higher than the enzyme activity observed a in the culture without glucose. However for all glucose concentrations tested, with exception of $1.0 \%$ and $2.0 \%$ glucose, the extracellular activity was higher than that of the intracellular one. The presence of glucose under SSF slightly decreased the level of extracellular invertase (figure 2B).

Table 2. Influence of carbon sources on the production of extracellular invertase in solid-state fermentation by Aspergillus caespitosus.

\begin{tabular}{lcc}
\hline Substrate/Carbon source & Invertase Activity $(\mathrm{U} / \mathrm{g})$ & Protein $(\mathrm{mg} / \mathrm{g})$ \\
\hline Wheat bran & $117.4 \pm 1.1$ & $1.8 \pm 0.7$ \\
Oat meal & $6.9 \pm 0.1$ & $6.4 \pm 0.5$ \\
Rice straw & 0 & 0 \\
Sugar cane bagasse & 0 & 0 \\
Corncob crushed & 0 & 0 \\
Cassava flour & $3.8 \pm 0.8$ & $1.7 \pm 0.3$ \\
Soy bean bran & $28.3 \pm 2.5$ & $15.6 \pm 1.0$ \\
Wheat bran + oat meal $(1: 1 ; \mathrm{w} / \mathrm{w})$ & $181.8 \pm 4.9$ & $17.6 \pm 0.7$ \\
Wheat bran + cassava flour $(1: 1 ; \mathrm{w} / \mathrm{w})$ & $92.1 \pm 3.5$ & $7.3 \pm 0.5$ \\
Wheat bran + soybean bran $(1: 1 ; \mathrm{w} / \mathrm{w})$ & $179.9 \pm 4.2$ & $24.3 \pm 1.1$ \\
\hline
\end{tabular}

The substrates were moistened with destilated water $(1: 1 ; \mathrm{w} / \mathrm{v})$ and the cultures were maintained on stove at $40^{\circ} \mathrm{C}$ with $70 \%$ of humidity for $72 \mathrm{~h}$. The medium humidity was $70-85 \%$.

Influence of temperature and salts solution on invertase production under SSF

The aqueous solution added to the solid substrate is important for the enzyme production. Among all solutions tested, the best result was verified with SR salt solution mixed with wheat bran, around 38\% higher if compared with distilled water, suggesting that the same ions present on solution are important to invertase production (data not shown). The production of invertase under SSF was dependent of incubation temperature and also of the SR salt solution proportion (table 3). The highest levels were verified when the fungus was incubated at $30^{\circ} \mathrm{C}$ for the all salt 
solution proportions tested if compared with the incubation at $40^{\circ} \mathrm{C}$. The maximal production was obtained with the proportion $1: 1(\mathrm{w} / \mathrm{v})$, and the activity at $30^{\circ} \mathrm{C}$ was around 1.24 -fold higher than that verified at $40^{\circ} \mathrm{C}$.
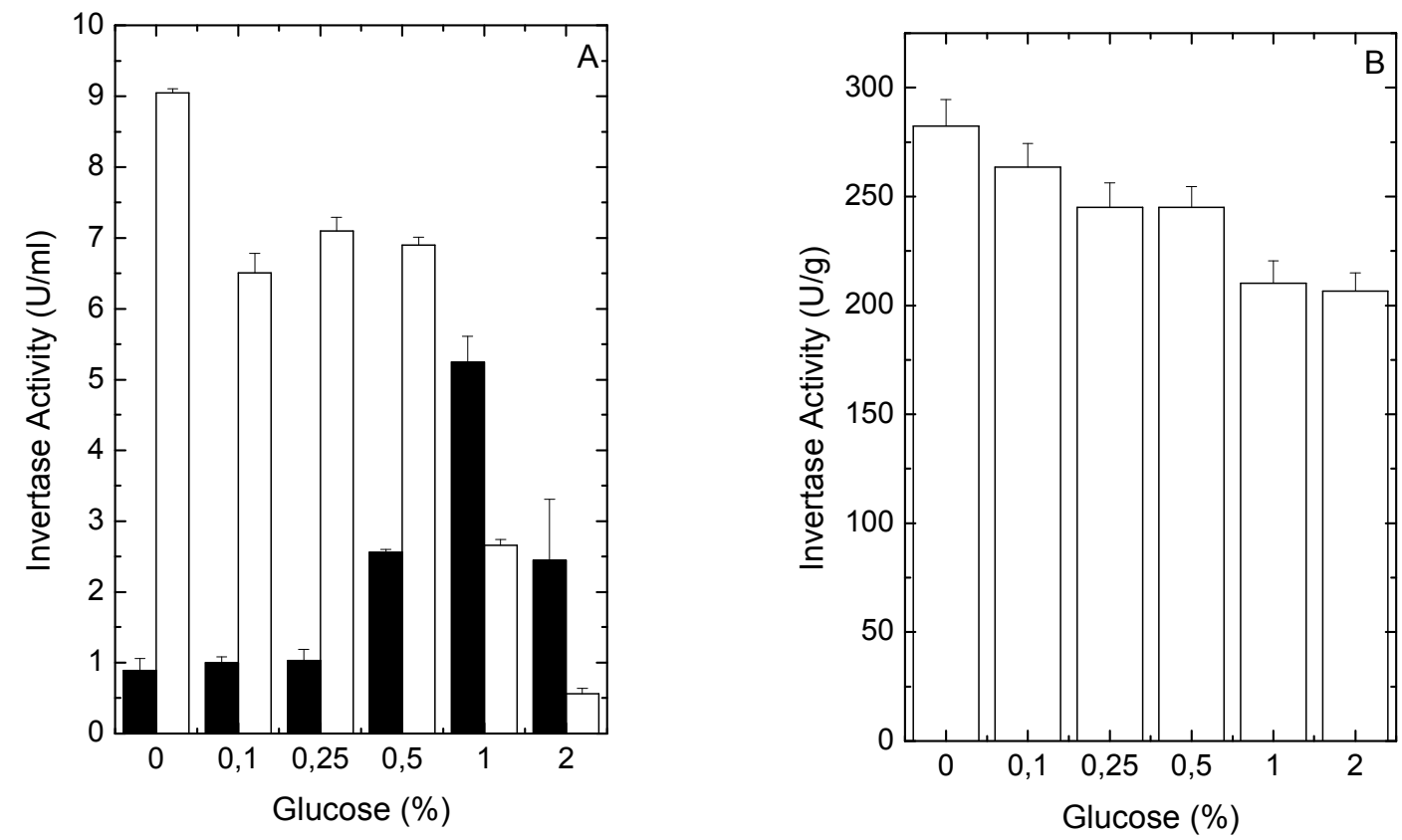

Figure 2. Effect of glucose on production of invertases in submerged (A) and state-solid (B) fermentations using wheat bran as carbon source. Symbols: $(\mathbf{\square})$ intracellular; $(\square)$ extracellular.

Table 3. Influence of temperature and proportion of SR salt solution added in state-solid fermentation on the production of invertase by Aspergillus caespitosus.

\begin{tabular}{ccccc}
\hline $\begin{array}{c}\text { Temperature } \\
\left({ }^{\circ} \mathrm{C}\right)\end{array}$ & $\begin{array}{c}\text { Proportion } \\
(\mathrm{w} / \mathrm{v})\end{array}$ & $\begin{array}{c}\text { Relative humidity } \\
(\%)\end{array}$ & $\begin{array}{c}\text { Invertase activity } \\
(\mathrm{U} / \mathrm{g})\end{array}$ & $\begin{array}{c}\text { Protein } \\
(\mathrm{mg} / \mathrm{g})\end{array}$ \\
\hline \multirow{3}{*}{30} & $1: 1$ & 85 & $303.4 \pm 7.0$ & $6.4 \pm 0.1$ \\
& $1: 2$ & 150 & $245.8 \pm 11.4$ & $4.2 \pm 0.1$ \\
& $1: 4$ & 285 & $188.7 \pm 37.2$ & $6.9 \pm 0.1$ \\
40 & $1: 1$ & 85 & $244.7 \pm 13.4$ & $4.7 \pm 0.1$ \\
& $1: 2$ & 150 & $244.7 \pm 13.8$ & $5.9 \pm 0.3$ \\
& $1: 4$ & 285 & $92.6 \pm 7.8$ & $9.5 \pm 0.2$ \\
\hline
\end{tabular}

The cultures were maintained on stove with $70 \%$ of humidity for $72 \mathrm{~h}$. 
Influence of nitrogen and phosphate on invertase 4.9-18.3\%). production

The invertase production was influenced for the supplementary addition of both nitrogen and phosphate sources added in SbmF and SSF (table 4). The intracellular invertase form produced on SbmF was enhanced around 1.4fold when used $\mathrm{Na}_{2} \mathrm{HPO}_{4}$ and peptone as phosphate and nitrogen source, respectively. However, the extracellular form was enhanced by all phosphate sources tested and only by $\left(\mathrm{NH}_{4}\right)_{2} \mathrm{SO}_{4}$ as nitrogen source. Different of the verified for intracellular form, peptone is not favorable for extracellular enzyme production. In SSF, the invertase production was similar with the control when added $\mathrm{Na}_{2} \mathrm{PO}_{4}$, but decreased in the presence of $\mathrm{KH}_{2} \mathrm{PO}_{4},\left(\mathrm{NH}_{4}\right)_{2} \mathrm{SO}_{4}$ and peptone (around
Optima temperature, thermal stability and optimum pH of activity

The optima temperature of activity for both, extracellular and intracellular invertases produced in $\mathrm{SbmF}$, was $60^{\circ} \mathrm{C}$ (figure 3A). However, the extracellular form produced in $\mathrm{SSF}$, exhibited an optima temperature of $50^{\circ} \mathrm{C}$ (figure $3 \mathrm{~A}$ ). The enzymes were stable at $50^{\circ} \mathrm{C}$, but the extracellular form was more stable than intracellular form (figure 3B). The optimum $\mathrm{pH}$ of activity for extracellular invertase produced in SSF was in the range of 4.0-6.0, 5.0-6.0 for enzyme produced in $\mathrm{SbmF}$ and 5.0 for the intracellular form (figure $3 \mathrm{C})$.

Table 4. Effect of several compounds on the production of invertases from A. caespitosus grown on SbmF and SSF.

\begin{tabular}{lccc}
\hline \multirow{2}{*}{\begin{tabular}{c} 
Compounds \\
\multicolumn{1}{c}{$(1 \% ; \mathrm{w} / \mathrm{v})$}
\end{tabular}} & \multicolumn{3}{c}{ SbmF (U/ml) } \\
\cline { 2 - 4 } & Intracellular & Extracellular & SSF (U/g) \\
\cline { 2 - 4 } & $4.4 \pm 0.2$ & $16.8 \pm 0.5$ & $245.0 \pm 2.1$ \\
\hline Without & $1.8 \pm 0.2$ & $18.1 \pm 0.8$ & $219.4 \pm 21.4$ \\
$\mathrm{KH}_{2} \mathrm{PO}_{4}$ & $6.3 \pm 0.1$ & $17.0 \pm 0.6$ & $257.2 \pm 0.8$ \\
$\mathrm{Na}_{2} \mathrm{HPO}_{4}$ & $1.3 \pm 0.1$ & $19.3 \pm 1.3$ & $200.1 \pm 23.5$ \\
$\left(\mathrm{NH}_{4}\right)_{2} \mathrm{SO}_{4}$ & $6.2 \pm 0.6$ & $14.7 \pm 1.7$ & $232.9 \pm 4.0$ \\
Peptone & & & \\
\hline
\end{tabular}

\section{DISCUSSION}

High levels of invertases were obtained when $A$. caespitosus was grown in SbmF (Khanna medium) and SSF using agroindustrial residues as carbon source. However, the production of extracellular invertase in SSF was 2.73-times superior when compared with the SbmF, with wheat bran.
The production of invertases using agroindustrial residues also was reported for $A$. ochraceus, with higher production in sugar cane bagasse (11).

The fungal invertase expression in SSF has been studied, as in Aspergillus niger $(3,23)$. The ideal process of SSF uses a solid phase that serves both as support and as nutrient sources. This process has been exploited for the production of 

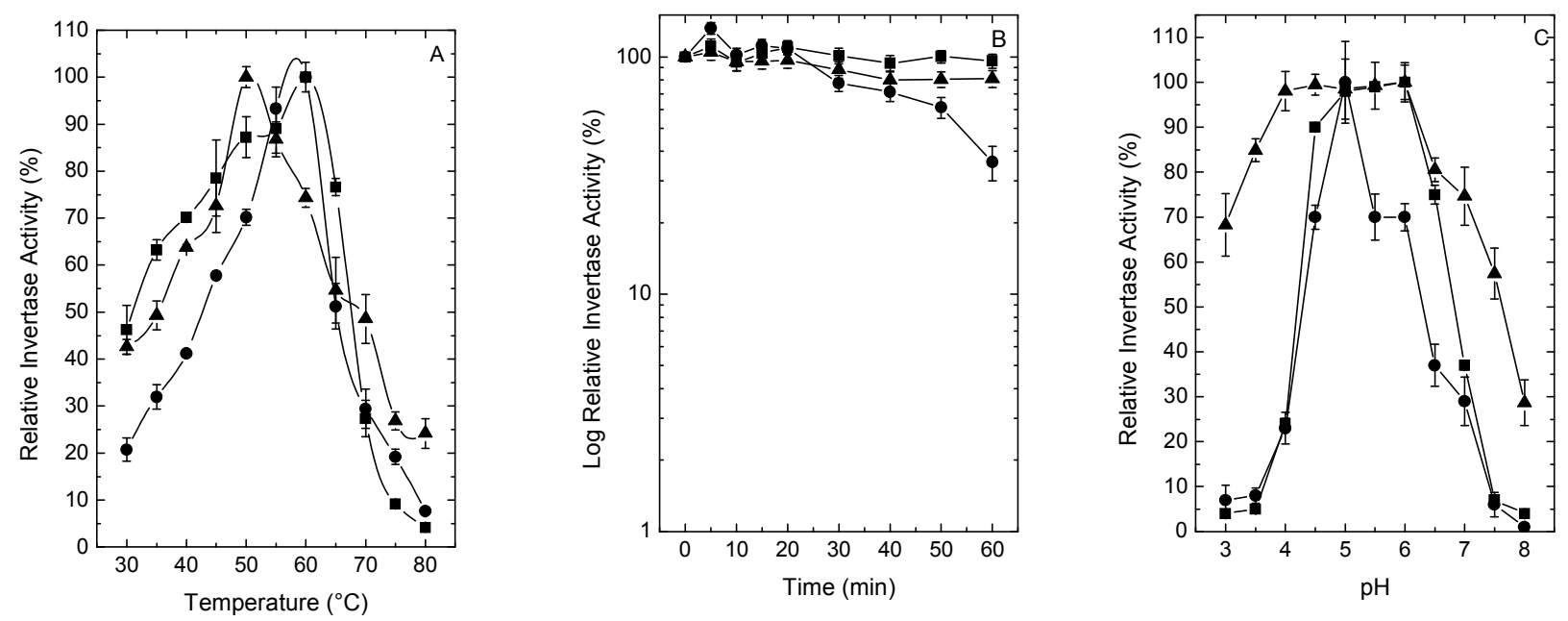

Figure 3. Optima temperature (A), thermal stability at $50^{\circ} \mathrm{C}(\mathrm{B})$ and optimum $\mathrm{pH}(\mathrm{C})$ of activity for intracellular $(\bullet)$ and extracellular ( $\boldsymbol{\square}$ ) invertase produced on SbmF, and extracellular invertase ( $\mathbf{A}$ ) produced on SSF by Aspergillus caespitosus.

value-added products, as for instance antibiotics, biofuel, organic acids, aroma compounds and enzymes (20). In addition, SSF permits the use of a variety of agricultural products and non-traditional substrates such as agroindustrial residues. The use of agroindustrial residues decreases the operational cost. Several factors can affect microbial growth and product synthesis under SSF, such as water activity and moisture content of the substrate, aeration and nutrients diffusion, temperature and $\mathrm{pH}$. The filamentous fungi are the best-adapted microorganisms for SSF due to their physiological, enzymological and biochemical properties (20). However, bacteria and yeasts also have been used for SSF cultivation (17). The production of invertases by $A$. caespitosus in SSF was better with lower humidity medium $(85 \%)$ than others analyzed conditions. In addition, the higher production of invertase in SSF than in SbmF can be attributed to differences in the induction and repression of enzyme synthesis or to differences in the quality of the enzymes, among others $(3,23)$.
The production of invertases by $A$. caespitosus under SbmF and SSF was affected by the addition of glucose. The extracellular form decreased, but the intracellular form increased approximately 5 -fold with glucose $1 \%$. Inhibition of extracellular invertase production by glucose was also observed for $A$. niger and A. nidulans (30), differing of that verified for A. ochraceus (11) and Aureobasidium pullulans (35). The repressive effect of glucose is known as carbon catabolic repression and is mediated by transcriptional regulation. In Aspergillus, the regulator creA prevents or decreases the transcription of genes subject to carbon catabolic repression. Usually, these genes are involved in the metabolism of alternative carbon sources (32). Thus, the fact that the presence of glucose in the culture medium of $A$. caespitosus increased the intracellular and decreased the extracellular invertase activities could be explained by two possibilities: i) A. caespitosus invertases synthesis are not controlled by a system containing a regulator similar to creA, but the secretory pathway can be negatively affected by 
higher glucose concentration, or ii) A. caespitosus possesses two invertase isoforms, one retained on the intracellular compartment, tolerant to glucose repression, and the other secreted into the medium, which is strongly repressed by glucose.

The production of invertases also was influenced by nitrogen and phosphate sources. In S. cerevisae GCB-K5 among all nitrogen sources tested, peptone gave maximum invertase production and among all phosphate sources, $\mathrm{KH}_{2} \mathrm{PO}_{4}$ was the better (27). According to Neto et al. (18), the nitrogen constituent has an important influence on the invertase production because there is a strong correlation between nitrogen equilibrium and productivity of cells.

The optima temperature of activity obtained for both, extracellular and intracellular invertases produced in SbmF, was similar of the value observed for invertase of $A$. ochraceus (11) and higher than observed for invertases of Bifidobacterium infantis (34), Aspergillus niger (14). But for the extracellular form produced in SSF, this value was similar of that obtained for enzyme of Fusarium solani (5). The enzymes were stable at $50^{\circ} \mathrm{C}$, but the extracellular form was more stable than intracellular form. At $60^{\circ} \mathrm{C}$, the extracellular enzyme produced in SSF was more stable than the extracellular enzyme produced in SbmF, with half-life $\left(t_{50}\right)$ of about $20 \mathrm{~min}$ (data not shown), higher than verified for Azotobacter chroococcum (8). The optimum $\mathrm{pH}$ for invertases produced in SbmF and SSF was in the range of 4.0-6.0. The range of $\mathrm{pH}$ of activity of 2.6-6.0 were reported for others microorganisms $(4-5,9,14,25)$.

In conclusion, Aspergillus caespistosus was a new good producer of invertases using agroindustrial residues and the best condition for production and secretion these enzymes was SSF with wheat bran moistened with SR salt solution $(1: 1, w / v)$, at $30^{\circ} \mathrm{C}$, for $72 \mathrm{~h}$. The temperature of $30^{\circ} \mathrm{C}$ also was used for invertase production with $A$. niger under SSF using polyurethane foam as an inert support (23). Enzyme production using agroindustrial residues is very interesting and possibility the use of SSF, diminishing costs and enhancer the productivity. In addition, they showed elevated temperature of activity and good thermal stability, acting on the large range of $\mathrm{pH}$. These properties are very attractive for biotechnological application in different sectors of food industries.

\section{ACKNOWLEDGEMENT}

This work was supported by grants Fundação de Amparo a Pesquisa do Estado de São Paulo (FAPESP) and Conselho de Desenvolvimento Científico e Tecnológico (CNPq). We thank Maurício de Oliveira for technical assistance.

\section{RESUMO}

\section{Produção de invertases termoestáveis por Aspergillus} caespitosus em fermentação submersa e em estado sólido usando resíduos agroindustriais como fonte de carbono

O fungo filamentoso Aspergillus caespitosus foi um bom produtor de invertases intracelular e extracelular em fermentação submersa (FSbm) ou em estado sólido (FES), usando resíduos agroindustriais como fonte de carbono, sendo que para ambas as condições de cultivo, a maior produtividade foi obtida empregando-se farelo de trigo. A produção da forma extracelular em FES mantido a $30^{\circ} \mathrm{C}$, por 72 horas, foi aumentada usando-se solução de sais SR (1:1, $\mathrm{m} / \mathrm{v}$ ) para umidificar o substrato, sendo aproximadamente 5,5 vezes maior se comparada a FSbm (Meio Khanna) com a mesma fonte de carbono. Entretanto, a mistura de farelo de trigo e farinha de aveia em FES levou a um aumento de 2,2 
vezes na produção enzimática se comparada ao uso isolado do farelo de trigo. A produção enzimática, em ambas as condições de cultivo, foi afetada pela adição suplementar de fontes de nitrogênio e fosfato. A adição de glicose em FSbm e em FES promoveu a diminuição da enzima extracelular, mas favoreceu um acúmulo intracelular de 3-5 vezes maior. A temperatura ótima de atividade para as invertases produzidas em FES e em FSbm foi de $50^{\circ} \mathrm{C}$ e $60^{\circ} \mathrm{C}$, respectivamente, sendo estáveis a $50^{\circ} \mathrm{C}$ por mais de 60 minutos. Todas as formas enzimáticas apresentaram atividade máxima em uma faixa de $\mathrm{pH}$ de 4.0-6.0.

Palavras-chave: Aspergillus caespitosus, $\beta$-Dfructofuranosidase, invertase, fermentação em estado sólido, fermentação submersa

\section{REFERENCES}

1. Adams, P.R. (1990). Mycelial amylase activities of thermophilic species of Rhizomucor, Humicola and Papulospora. Mycopatologia, 112, 35-37.

2. Alberto, F.; Bignon, C.; Sulzenbacher, G.; Henrissat, B.; Czjzek, M. (2004). The three-dimensional structure of invertase ( $\beta$-fructosidase) from Thermotoga maritima reveals a bimodular arrangement and an evolutionary relationship between retaining and inverting glycosidases. J. Biol. Chem., 279, 18903-18910.

3. Aranda, C.; Robledo, A.; Loera, O.; Contreras-Esquivel, J.C.; Rodrigues, R.; Aguilar, C.N. (2006). Fungal invertase expression in solid-state fermentation. Food Technol. Biotechnol., 44(2), 229-233.

4. Belcarz, A.; Ginalska, G.; Lobarzewski, J.; Penel, C. (2002). The novel non-glycosilated invertase from Candida utilis (the properties and the conditions of production and purification). Biochem. Biophys. Acta, 1594, 40-53.

5. Bhatti, H.N.; Asgher, M.; Abbas, A.; Nawaz, R.; Sheiki, M.A. (2006). Studies on kinetics and thermostability of a novel acid invertase from Fusarium solani. J. Agric. Food. Chem., 54, 4617-4623.

6. Chaudhuri, A.; Bharadwaj, G.; Maheshwari, R. (1999). An unusal pattern of invertase activity development in the thermophilic fungus Thermomyces lanuginosus. FEMS Microbiol. Lett., 177, 39-45.
7. Cheng, T.C.; Duan, K.J.; Sheu, D.C. (2005) Immobilization of $\beta$ fructofuranosidase from Aspergillus japonicus on chitosan using tris(hydroxymethyl)phosphine or glutaraldehyde as a coupling agent. Biotechnol. Lett., 27, 335-338.

8. De la Vega, M.; Cejudo, F.; Paneque, A. (1991). Purification and properties of an extracellular invertase from Azotobacter chroococcum. Enzyme Microbial Technol., 13, 267-271.

9. Fernández, R.C.; Maresma, B.G.; Juárez, A.; Martinez, J. (2004). Production of fructooligosaccahrides by $\beta$-fructofuranosidase from Aspergillus sp 27H. J. Chem. Technol. Biotechnol., 79, 268-272.

10. Guimarães, L.H.S.; Peixoto-Nogueira, S.C.; Michelin, M.; Rizzatti, A.C.; Sandrim, V.C.; Zanoelo, F.F.; Aquino, A.C.M.M.; Junior, A.B. and Polizeli, M.L.T.M. (2006). Screening of filamentous fungi for production of enzymes of biotechnological interest. Braz. J. Microbiol., $37,474-480$.

11. Guimarães, L.H.S.; Terenzi, H.F.; Polizeli, M.L.T.M.; Jorge, J.A (2007). Production and characterization of a thermostable extracellular $\beta$-D-fructofuranosidase produced by Aspergillus ochraceus with agroindustrial residues as carbon sources. Enzyme Microbial Technol., $42,52-57$.

12. Herwig, C.; Doerries, C.; Marison, I.; von Stockar, U. (2001). Quantitative analysis of the regulation scheme of invertase expression in Saccharomyces cerevisae. Biotechnol. Bioeng., 76, 247-258.

13. Khanna, P.; Sundari, S.S.; Kumar, N.J. (1995). Production, isolation and partial purification of xylanase from Aspergillus sp. World J. Microbiol. Biotechnol., 1, 242-243.

14. L'Hocine, L.; Wang, Z.; Jiang, B.; Xu, S. (2000). Purification and partial characterization of fructosyltransferase and invertase from Aspergillus niger AS0023. J. Biotechnol., 81, 73-84.

15. Lowry, O.H.; Rosebrough, N.J.; Farr, A.L.; Randall, R.J. (1951). Protein measurement with the Folin phenol reagent. J. Biol. Chem., $193,265-275$.

16. Miller, G.L. (1959). Use of dinitrosalicylic acid reagent for determination of reducing sugar. Anal. Chem., 31, 426-428.

17. Mitchell, D.A.; Lonsane, B.K. (1992). Solid Substrate Cultivation. Elsevier Sci. Publ. Ltd; London and New York, pp. 1-13.

18. Neto, J.; Infanti, P.; Vitolo, M. (1996). Hexokinase production from Saccharomyces cerevisiae: culture conditions. Appl. Biochem. Biotechnol., 57/58, 407-412.

19. Peralta, R.M.; Terenzi, H.F.; Jorge, J.A. (1990). $\beta$-D-Glycosidase activities of Humicola grisea: biochemical and kinetic characterization of a multifunctional enzyme. Biochim. Biophys. Acta, 1033, 243-249. 
20. Pérez-Guerra, N.; Torrado-Agrasar, A.; López-Macias, C.; Pastrana, L. (2003). Main characteristics and applications of solid substrate fermentation. Electron. J. Environ. Agric. Food. Chem., 2(3), 343-350.

21. Raper, K.B.; Fennel, D.I. (1965). The Genus Aspergillus. Willians and Wilkins, Baltimore.

22. Rizzatti, A.C.S.; Jorge, J.A.; Terenzi, H.F.; Rechia, C.G.V.; Polizeli, M.L.T.M. (2001). Purification and properties of a thermostable extracellular $\beta$-D-xylosidase produced by thermotolerant Aspergillus phoenicis. J. Ind. Microbiol. Biotechnol., 259, 156-160.

23. Romero-Gómez, S.; Augur, C.; Viniegra-González, G. (2000). Invertase production by Aspergillus niger in submerged and solid-state fermentation. Biotechnol. Lett., 22, 1255-1258.

24. Rubio, M.C.; Navarro, A.R. (2006). Regulation of invertase synthesis in Aspergillus niger. Enzyme Microbial Technol., 39, 601-606.

25. Rubio, M.C.; Runco, R.; Navarro, A.R. (2002). Invertase from a strain of Rhodotorula glutinis. Phytochemistry, 61, 605-609.

26. Sangeetha, P.T.; Ramesh, M.N.; Prapulla, S.G. (2005). Recent trends in the microbial production, analysis and application of Fructooligosaccharides. Trends Food Sci. Technol., 16, 442-457.

27. Shafiq, K.; Ali, S.; ul-Haq, I. (2002). Effect of different mineral nutrients on invertase production by Saccharomyces cerevisae GCBK5. Biotechnology, 1, 40-44.

28. Sturm, A. (1999). Invertases. Primary structure, functions, and roles in plant development and sucrose partitioning. Plant Physiol., 121, 1-7.
29. Sturm, A.; Chrispeels, M.J. (1990). cDNA cloning of carrot extracellular $\beta$-fructofuranosidase and its expression in response to wounding and bacteria infection. Plant Cell, 2, 1107-1119.

30. Vainstein, M.H.; Peberdy, J.F. (1991). Regulation of invertase in Aspergillus nidulans: effect of different carbon sources. J. Gen. Microbiol., 137, 315-321.

31. Vandenberghe, L.P.S.; Soccol, C.R.; Pandey, A.; Lebeault, J.M. (2000) Solid-state fermentation for the synthesis of citric acid by Aspergillus niger. Biores. Technol., 74, 175-178

32. vanKuyk, P.A.; Diderich, J.A.; MacCabe, A.P.; Herrero, O.; Ruijter, G.J.G.; Visser, J. (2004). Aspergillus niger mstA encodes a high-affinity sugar $/ \mathrm{H}^{+}$symporter which is regulated in response to extracellular $\mathrm{pH}$. Biochem. J., 379, 375-383.

33. Vargas, W.; Cumino, A.; Salermo, L.S. (2003). Cyanobacterial alkaline/neutral invertases. Origin of sucrose hydrolysis in the plant cytosol? Planta, 216, 951-960.

34. Warchol, M.; Perrin, S.; Grill, J.P.; Schneider, F. (2002). Characterization of a purified $\beta$-fructofuranosidase from Bifidobacterium infantis ATCC 15697. Lett. Appl. Microbiol., 15697, 462-467.

35. Yoshikawa, J.; Amachi, S.; Shinoyama, H.; Fujii, T. (2006). Multiple $\beta$ fructoduranosidases by Aureobasidium pullulans DSM 2404 and their roles in the fructooligosaccharide production. FEMS Microbiol. Lett., $265,159-163$ 